\title{
Response of Diamesa spp. (Diptera: Chironomidae) from Alpine streams to newly emergent contaminants and pesticides
}

\author{
Valeria LENCIONI*, Francesco BELLAMOLI, Paola BERNABÒ, Francesco MIARI, Alberto SCOTTI \\ Department of Invertebrate Zoology and Hydrobiology, MUSE - Museo delle Scienze, Corso del Lavoro e della Scienza 3, 38122 \\ Trento, Italy \\ *Corresponding author: valeria.lencioni@muse.it
}

\begin{abstract}
Acute toxicity and genotoxic activity of 11 pollutants were investigated in wild populations of Diamesa cinerella and Diamesa zernyi (Diptera Chironomidae) from two alpine streams (Italian Alps). D. cinerella was collected in two sites on the non-glacial Vermigliana stream, 50 m-upstream and 5-m downstream of the Wastewater Treatment Plant (WTP) at the Tonal Pass (1799 m a.s.1.). D. zernyi was collected in the Presena glacial stream, close to the glacier snout (2685 m a.s.1.). IV-instar larvae were exposed for 24$96 \mathrm{~h}$ to increasing concentrations of three drugs (ibuprofen-IBU, furosemide-FUR, trimethoprim-TMP), three personal care products (triclocarban-TCC, tonalid-TON, sucralose-SUCR), and five pesticides (boscalid-BOS, captan-CAP, chlorpyrifos-CPS, metolachlorMET, terbuthylazine-TER). The experimental concentrations were from one to several million times higher than the highest environmental concentration (EC) measured in the study sites. Two mixtures of pesticides were also prepared: MIX $1 \mathrm{~K}=10^{3} \mathrm{x} E C$ of CPS, MET and TER, and MIX 10K $=10^{4} \mathrm{x}$ EC of CPS, MET and TER. Species- and site-specific responses were observed for both tests. On the basis of survival data, both species resulted very resistant to pharmaceuticals (mainly to FUR for which no effects on survival and movement or pupation were observed), and more sensitive to pesticides (mainly to CPS, MET and CAP). Genotoxicity tests (Comet assay) highlighted a WTP effect under natural conditions and a genotoxic effect for 9 of the 11 tested compounds. Overall, a clear gradient of increasing resistance in larvae from the least (PR0) to the most polluted (TP_dw) site was highlighted by both tests, ecotoxicological and of genotoxicity, as also expected according to species autecology (D. zernyi is restricted to very cold and pristine habitats). D. cinerella living downstream of the effluent accumulates a significantly higher DNA damage than the other populations, highlighting a basal physiological stress condition in nature. It is plausible that these larvae possess chemical resistance strategies to survive already under natural conditions. Diamesa spp. exhibited a higher toxic resistance than any other model species tested to date under the same pollutants, probably associable to its strong cold resistance. The results emphasised that the measured concentrations of Contaminants of Emerging Concern (CECs) and pesticides seem to be far below those required to cause acute effects. However, the effects on freshwater communities of prolonged exposure to mixture of trace CECs and pesticides remain unknown.
\end{abstract}

Key words: Pollution; climate change; glacier-fed streams; sub-lethal effects; acute toxicity; genotoxicity.

Contributions: VL, experiments concept and design; FB, FM, AS, toxicological tests performing; FB, VL, data processing; $\mathrm{PB}$, collaboration on data processing, performing statistical analyses; VL, manuscript writing and revision.

Received: February 2018. Accepted: June 2018.

This paper was presented at the 20 ${ }^{\text {th }}$ International Symposium on Chironomidae, Trento, Italy, 2-8 July 2017. Session: Toxicology and Adaptive Biology.

\section{INTRODUCTION}

Freshwater wildlife at high altitude is threatened by climate change. Glacier retreat will alter hydrological and thermal regimes, sediment transport and biogeochemical fluxes in glacier-fed streams (kryal), with effects on biodiversity (Milner et al., 2009). Glacier-fed streams are typically colonized by few animal taxa, with chironomids (Diptera, Chironomidae) dominant as individual and species number in the invertebrate community (Rossaro et al., 2016).

Long-term ecological studies have highlighted changes in the invertebrate community structure and functional diversity in glacier-fed streams due to glacier retreat (Milner et al., 2017; Brown et al., 2018), with loss of the most cold-stenothermal kryal inhabitants (Lencioni, 2018). In particular, some cold stenothermal Diamesa species (Chironomidae Diamesinae) might be seriously threatened by extinction accompanied by loss of the kryal habitat (Lencioni et al., 2015). Among these, the "ice fly" Diamesa steinboecki Goetghebuer, the "flagship" species of the European glacier-fed streams, already disappeared or surviving only as brachypterous populations in Alpine catchments with small feeder glaciers (with a surface $<<1$ $\mathrm{km}^{2}$ ) (Lencioni, 2018).

Climate change is not the only threat for the alpine fauna, but exposure to chemical contamination by pollutants 
carried to the glaciers by atmospheric transport and released in the ice-melt waters (Guzzella et al., 2016; Steinlin et al., 2016) is growing. Among these, pesticides and "emerging contaminants" (CECs) (e.g., PPCPs=pharmaceuticals and personal care products) (Ferrario et al., 2017). PPCPs include human and veterinary drugs and many consumer chemicals used for example in fragrances, sun-screen agents, lipsticks, shampoos, cosmetic and food products (Daughton and Ternes, 1999). In Alpine environments, even if the measured concentrations of the detected contaminants may be much lower than those causing acute effects (Chiogna et al., 2016), prolonged exposure to mixture of CECs may damage macroinvertebrate communities, with cascade effects on the river food webs. CECs are emitted also by Wastewater Treatment Plants (WTPs), representing an emerging environmental problem in Alpine rivers strongly affected by tourism, where pollution level peaks during holidays (Mandaric et al., 2017).

While it is known that Diamesa spp. survives shortterm heat shocks $\left(1 \mathrm{~h}\right.$ shock: $\left.\mathrm{LT} 50=32^{\circ} \mathrm{C}, \mathrm{LT} 100=35^{\circ} \mathrm{C}\right)$ by developing a Heat Shock Response (Lencioni et al., 2013), to our knowledge no information is available on toxic resistance in Diamesa spp. or in other alpine stream invertebrates. Furthermore, ecotoxicological literature on chironomids is limited to Chironomus genus (Bernabò et al., 2017). To evaluate the ecotoxicological and genotoxic effects of 11 pollutants were tested in two Diamesa species collected in two Alpine streams polluted by pharmaceuticals, personal care products and pesticides with different origin (WTPs and atmospheric transport). On the basis of species autecology (D. zernyi is restricted to very cold and pristine habitats, Lencioni and Rossaro, 2005) and natural level of environmental contamination, species- and site-specific responses were expected.

\section{METHODS}

\section{Animal sampling and rearing}

Laboratory experiments were performed on IV-instar larvae of Diamesa zernyi Edwards collected in the Rio Presena at $2685 \mathrm{~m}$ asl (PR0), within $20 \mathrm{~m}$-downstream of the glacier snout, in late summer 2016 (1, 6, 14 September 2016) and on IV-instar larvae of Diamesa cinerella Meigen collected in the Vermigliana Stream at $1799 \mathrm{~m}$ asl, in winter 2016 (7, 9, 14 March 2016). The two sites on the Vermigliana stream were located 70 m-upstream (TP_up) and $50 \mathrm{~m}$-downstream (TP dw) of the effluent of the Tonale Pass WTP, designed to serve 10,000 equivalent inhabitants. This plant collects wastewater from a large ski resort (Mandaric et al., 2017). The three sites are located in the Noce River catchment, in Trentino (NE-Italy, $46^{\circ} \mathrm{N}$, $\left.10^{\circ} \mathrm{E}\right)$ (Fig. 1). The main physicochemical features of the three sites are reported in Tab. S1.
The larvae were collected with a $30 \times 30 \mathrm{~cm}$ pond net (mesh size $100 \mu \mathrm{m}$ ) (Scubla SNC, Italy), sorted in the field with tweezers, transferred to plastic bottles filled with stream water, and transported to the laboratory in a cooling bag. Species confirmation was performed within $24 \mathrm{~h}$ of sampling using a stereomicroscope (MZ 7.5; Leica Microsystems, Germany; 50×) according to the method described by (Rossaro and Lencioni, 2015). The larvae were maintained in 1-L glass aquaria with stream water in a thermostatic chamber (ISCO, model FTD250-plus; Teledyne Isco Inc., Lincoln, NE, USA) at $2{ }^{\circ} \mathrm{C}$, with aeration to maintain dissolved oxygen at higher than $80 \%$ saturation. The incubation temperature $\left(2^{\circ} \mathrm{C}\right)$ approximated the water temperature measured in the two streams on the first day of sampling using a multiparametric probe Hydrolab Quanta (Hydrolab Quanta, Hydrolab Corporation $\AA$, TX, USA) (Tab. S1). To acclimate the larvae to exposure conditions, $24 \mathrm{~h}$ prior to each experiment randomly selected larvae were removed from the rearing aquarium and transferred to a $500-\mathrm{mL}$ beaker (approximately 40 larvae per beaker) containing $200 \mathrm{~mL}$ of reconstituted water (RW) prepared according to (Holdway, 2005): hard for larvae from the Vermigliana stream and soft-medium for larvae from the Presena stream, according to the natural conductivity (Tab. S1). During acclimatization and exposure, the larvae were maintained with aeration at $2 \pm 1{ }^{\circ} \mathrm{C}$ without food, to empty the gut.

\section{Treatment protocol}

All larvae were exposed to four PPCPs selected on the basis of their environmental concentrations (EC) (referred to winter in the Vermigliana stream and to summer in the Presena stream), risk level and state of knowledge on their effects on aquatic wildlife (Tab. S2): ibuprofen-IBU (NSAID, nonsteroidal anti-inflammatory), furosemideFUR (diuretic), trimethoprim-TMP (antibiotic) and triclocarban-TCC (antibacterial). The larvae collected in the most pristine site, PR0, were exposed to other seven pollutants, of which two PPCPs (the fragrance tonalidTON and the food artificial sweetener sucralose-SUCR) and five pesticides: boscalid-BOS (fungicide), captanCAP (fungicide), metolachlor-MET (herbicide), terbuthylazine-TER (herbicide), chlorpyrifos-CPS (insecticide) (Tab. S2) and to two mixtures of pesticides: i) $\mathrm{MIX} 1 \mathrm{~K}=10^{3} \mathrm{x}$ EC of CPS, MET and TER; ii) MIX $10 \mathrm{~K}=10^{4} \mathrm{x}$ EC of CPS, MET and TER.

The ecotoxicological effects of the 11 pollutants were evaluated by 21 acute toxicity tests (one per species-sitepollutant, from 24 to $96 \mathrm{~h}$ ) to estimate the Lethal Concentrations (LC). The tests were stopped before $96 \mathrm{~h}$ when the mortality overcame $50 \%$. Five to ten exposure concentrations for each pollutant were selected on the basis of toxicological parameters (LC50/EC50) published for other aquatic species (Daphnia magna, Planorbis 
carinatus, Hydra attenuata, Hydra vulgaris, Nitocra spinipes, Chironomus tentans, Chironomus plumosus) (Tab. 1), the environmental concentrations and the solubility of the substances (Tab. S2). For TON, SUCR and TER, only one-two experimental concentrations were tested, corresponding to the maximum solubility in acetone (for TON), DMSO (for TER) or water (for SUCR). All pollutants (with the exception of TON and SUCR) were dissolved in DMSO to favour chemical solubilisation in water, with a final $\mathrm{pH}$ of 7.7. DMSO did never exceed $2 \%$ of final volume to avoid harmful effects (Dong et al., 2013). At this concentration, DMSO did not cause genotoxicity in Diamesa spp. and other invertebrates from the Vermigliana stream (Baetidae and Rhyachophilidae) (unpublished data). Aliquots of stock solution were diluted with RW. The experimental concentrations ranged from once to 50 million times the predicted/measured concentrations in the two streams (Tab. S2).

The genotoxicity of the 11 pollutants was assessed with the single-cell gel electrophoresis assay (SCGE), also known as Comet assay, to detect DNA damage in individual cells in terms of strand breaks that represent one of the major damage to DNA via oxidative stress (Valverde and Rojas, 2009). The assay was performed according to Bernabò et al. (2017), without isolating individual celltypes (Lee et al., 2009; Martínez-Paz et al., 2013). Eighty-three tests were performed at sublethal concentrations of each pollutant $(=\mathrm{LC} 10$ estimated, LOEC, NOEC or LCx calculated where $\mathrm{x}<<50$, see Statistical analyses; Tab. 1) in the same laboratory conditions as acute toxicity tests. Genotoxicity was evaluated also in larvae maintained in RW within $24 \mathrm{~h}$ from the sampling, to

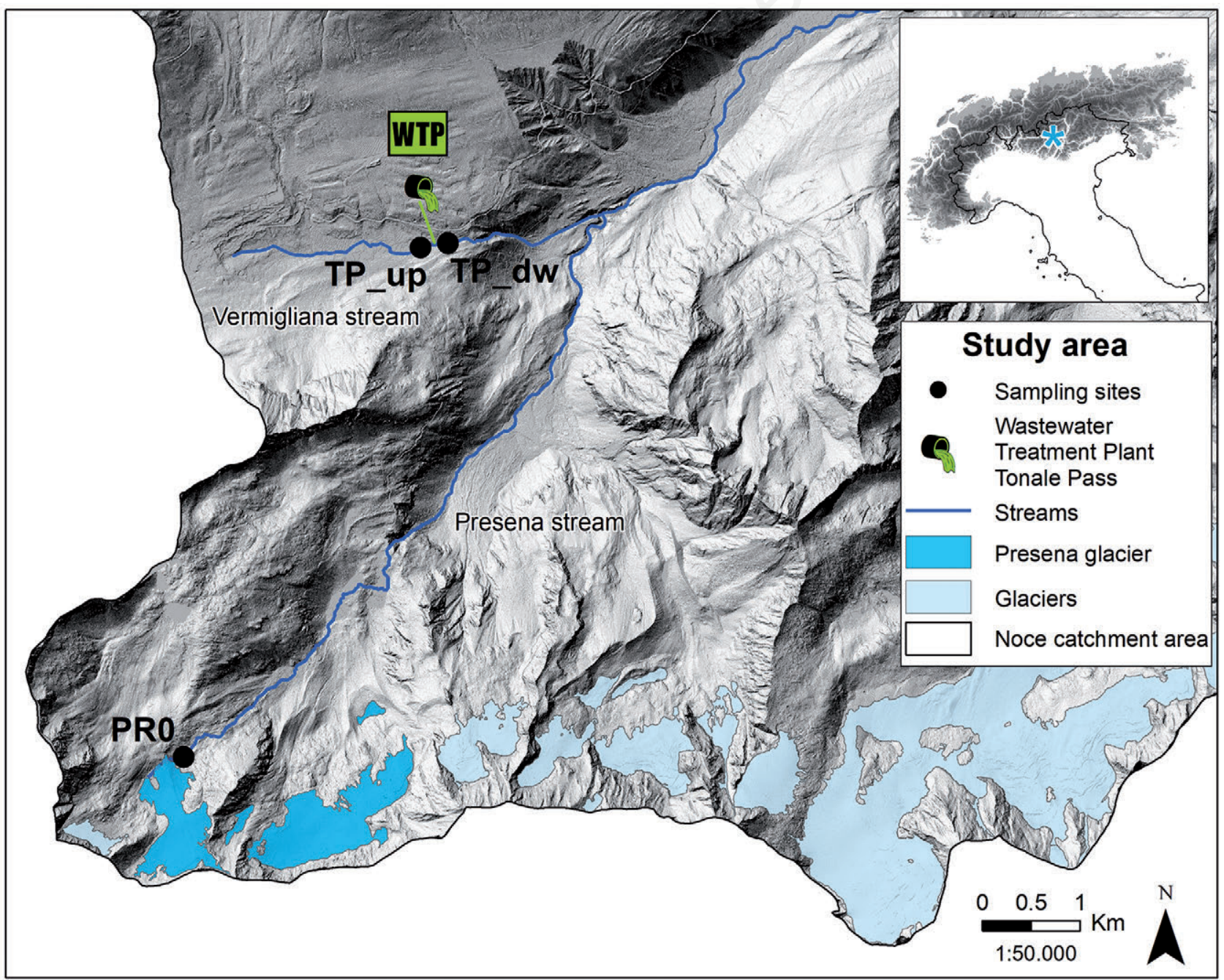

Fig. 1. Study area (Trentino, NE-Italy, $46^{\circ} \mathrm{N}, 10^{\circ} \mathrm{E}$ ). PR0, kryal site on the Presena stream; TP , sites on the Vermigliana stream, upstream (TP_up) and downstream (TP_dw) from the Tonale Pass (TP) WTP. 
highlight any basal DNA damage under natural conditions. Cells were analyzed at the fluorescence microscope with the TriTek Comet ScoreTM software (TriTek Corp) and the Olive Tail Moment (OTM) was used for assessing DNA damage. OTM is a measure of both amount of DNA in the tail and distribution of DNA in the tail and it is calculated as the product of the tail length and the fraction of total DNA in the tail=(tail mean - head mean) $\mathrm{x}$ (tail \%DNA/100) (Olive and Banáth, 2006).

For each series of experiments (acute toxicity tests and Comet assay), three biological replicates, with five larvae each, were planned for each exposure concentration and for the appropriated controls. During each test, larvae were taken in $100 \mathrm{~mL}$ glass bottles, containing $20 \mathrm{~mL}$ test solution or the solvent diluted with RW (control), with test solutions renewed daily. Negative controls ( $\mathrm{Ctrl}=$ reconstructed water plus solvent at the same concentration of toxicant tested solution) were carried out during the period of exposure in all experimental replicates (Villa et al., 2018). After each exposure of $24 \mathrm{~h}$, larvae that moved spontaneously were considered active, whereas those that moved only following a tactile stimulus were considered suffering. Survival was determined by the sum of active and suffering (=alive) larvae. Immobile larvae were considered dead. Due to mortality or pupation of larvae in the genotoxicity tests (depending on the exposure concentration, e.g., 10\% mortality at $\mathrm{LC10}$ ), extra replicates were added when necessary to obtain a minimum number of five live larvae for each series of experiments. In all, 2710 larvae were tested for acute toxicity ( 835 of $D$. zernyi and 1875 of $D$. cinerella) and 400 for genotoxicity assay (200 of D. zernyi and 200 of D. cinerella).

\section{Statistical analyses}

Toxicological parameters, i.e. the concentrations causing $10 \%$ and $50 \%$ of mortality (=LC10 and LC50 with $95 \%$ fiducial limits) were estimated with a Weibull distribution according to Ritz et al. (2015) using R (version 3.2.4) and "drc" package (version 3.0-1). In three cases it was not possible to estimate significantly the LC10 and LC50: i) when mortality was $<50 \%$ after $96 \mathrm{~h}$ : in this case a value of $\mathrm{LCx}$ was calculated from survival data at the highest pollutant concentration $(=\mathrm{Cmax})$; ii) when all larvae were found alive after $96 \mathrm{~h}, \mathrm{Cmax}$ was considered as a NOEC (=No Observed Effect Concentration); iii) when some larvae where found suffering or pupated after $96 \mathrm{~h}, \mathrm{Cmax}$ was considered as a LOEC (Lowest Observed Effect Concentration).

Comet assay data were analysed using KruskalWallis test followed by Dunn test multiple comparisons. Three levels of significance are reported: ${ }^{*} \mathrm{P} \leq 0.05$, **P $\leq 0.01,{ }^{* * *} \mathrm{P} \leq 0.001$. The software GraphPad Prism 7 was used to statistically analyse and graph the Comet assay data.

\section{RESULTS}

\section{Acute toxicity}

Toxicological parameters estimated or calculated in the two target species are reported in Tab. 1. Only three pollutants exhibited a significant negative effect on survival: CAP (LC10 $=3.14 \mathrm{mg} \mathrm{L}^{-1}$; LC50 $=81.06 \mathrm{mg} \mathrm{L}^{-1}$; $24 \mathrm{~h}$ ), CPS (LC10=1.06 $\mu \mathrm{g} \mathrm{L}^{-1}$; LC50 $=5.24 \mu \mathrm{g} \mathrm{L}^{-1} ; 48 \mathrm{~h}$ ) and MET (LC10 $=27.40 \mathrm{mg} \mathrm{L}^{-1} ; \mathrm{LC} 50=84.12 \mathrm{mg} \mathrm{L}^{-1} ; 72$ h), all in D. zernyi (Tab. 1, Fig. 2). BOS and TER seemed to be harmless, with no effects by BOS (NOEC $=500 \mu \mathrm{g}$ $\mathrm{L}^{-1}, 96 \mathrm{~h}$ ) and $20 \%$ of mortality by TER after $96 \mathrm{~h}$ at 25 $\mathrm{mg} \mathrm{L}^{-1}$. D. zernyi larvae exhibited a high resistance also to the two mixtures of pesticides, with $3 \%$ of mortality after $72 \mathrm{~h}$ in the mixture with the lowest concentration (MIX $1 \mathrm{~K}$ ) and $13 \%$ after $24 \mathrm{~h}$ in that one more concentrated (MIX 10K).

For TCC, SUCR and TON some mortality (from 7 to $33 \%$; Tab. S2) was detected only after $96 \mathrm{~h}$ of exposure at the highest concentration of the product $\left(100 \mu \mathrm{g} \mathrm{L}^{-1}\right.$ of TCC, $42.7 \mathrm{~g} \mathrm{~L}^{-1}$ of SUCR and $100 \mathrm{mg} \mathrm{L}^{-1}$ of TON). Among these, only TCC caused mortality in all Diamesa populations, after $96 \mathrm{~h}$ at $100 \mu \mathrm{g} \mathrm{L} \mathrm{L}^{-1}$ : LC7 in D. zernyi, LC13 in D. cinerella from TP_up and LC33 in D. cinerella from TP $d w)$. Furosemide seemed the least harmful substance for the two species in the three sites $(\mathrm{NOEC}=500$ $\mathrm{mg} \mathrm{L}^{-1}, 96 \mathrm{~h}$ ), followed by TMP (NOEC and LOEC $=400$ $\mathrm{mg} \mathrm{L}^{-1}, 96 \mathrm{~h}$ in D. cinerella from TP up and D. zernyi from PR0 respectively), IBU (NOEC $=100 \mathrm{mg} \mathrm{L}^{-1}, 96 \mathrm{~h}$ ) in $D$. cinerella from TP $\mathrm{dw}$ and BOS (NOEC $=500 \mu \mathrm{g} \mathrm{L}^{-1}, 96 \mathrm{~h}$ ) in D. zernyi from PR0. In all other cases, a LCx was calculated, from LC3 $72 \mathrm{~h}$ for the mixture $1 \mathrm{~K}$ to LC33 96 $\mathrm{h}$ for IBU both in D. zernyi (Tab. 1).

Overall, some drugs were more toxic for the upstream D. cinerella population (i.e., IBU for which a mortality of $7 \%$ was detected at $100 \mathrm{mg} \mathrm{L}^{-1}$ after $96 \mathrm{~h}$ ) and others for the downstream one (i.e., TMP for which a mortality of $7 \%$ was detected at $400 \mathrm{mg} \mathrm{L}^{-1}$ after $96 \mathrm{~h}$ ). Among the drugs, only under IBU exposure, some suffering signals were detected in the other species, D. zernyi, with $33 \%$ of mortality after $96 \mathrm{~h}$ at $100 \mathrm{mg} \mathrm{L}^{-1}$.

\section{Genotoxic activity}

A basal level of DNA damage was detected in the larvae not exposed to pollutants (Fig. 3A), with $D$. cinerella from TP_dw showing significantly more damage than the other two populations.

This population accumulated less DNA damages than that living upstream when exposed to sub-lethal concentrations of the three drugs (FUR, IBU and TMP) and the antibacterial (TCC) after $24 \mathrm{~h}$ (Fig. 3C). At this time of exposure, only IBU caused a significant damage in $D$. cinerella from TP_dw, while in that one living in 
TP up also FUR and TCC exhibited a significant genotoxic effect. After $96 \mathrm{~h}$ of exposure, a genotoxic activity remained for IBU in $D$. cinerella from TP_dw and only for TCC upstream (Fig. 3D). D. zernyi resulted the most sensitive species, accumulating, after $96 \mathrm{~h}$ of exposure, DNA damages by all four pollutants tested also in D. cinerella (Fig. 3D). Even the two mixtures (MIX 1K and MIX 10K) and four of the pollutants tested only in $D$. zernyi (SUCR, TON, BOS and MET) caused genotoxicity (Fig. 3B).

\section{DISCUSSION}

Species- and site-specific responses were observed for both tests, according to our hypothesis. On the basis of survival data, both species were very resistant to pharmaceuticals (mainly to FUR that did not affect survival or fitness), and more sensitive to pesticides (mainly to CPS, MET and CAP - only for these three chemicals were estimates of significant LC10 and LC50 possible with the Weibull distribution). These results confirmed the high-hazard for the aquatic environments of the insecticide CPS (classified as very high-risk substance) and of the fungicide CAP (classified as highrisk substance) and suggest a high-hazard category for the as-yet undefined MET (Tab. S2; Lencioni et al., 2017). However, $50 \%$ mortality was observed only after $72 \mathrm{~h}$ to an exposure concentration of MET about 18 million times higher than its EC, suggesting that the environmental concentrations are appropriate for this chironomid fauna.

Starting from these results, it was surprising that only $3 \%$ mortality was observed to mixed pesticides including also CPS and MET: after $72 \mathrm{~h}$ in a solution with CPS, MET and TER $1000 \mathrm{x}$ higher than their EC. A non-additive toxic effect of pesticide mixtures was already been observed for other organisms, probably due to reciprocal interactions between pesticides with different chemical properties and

Tab. 1. Acute toxicity of eleven pollutants in Diamesa cinerella from two sites (TP_up and TP_dw) and Diamesa zernyi from PR0.

\begin{tabular}{|c|c|c|c|c|c|}
\hline \multirow{3}{*}{$\begin{array}{l}\text { Species } \\
\text { Diamesa cinerella }\end{array}$} & \multirow{3}{*}{$\begin{array}{l}\text { Toxicant } \\
\text { FUR }\end{array}$} & \multirow{3}{*}{$\begin{array}{l}\text { Site } \\
\text { TP_up } \\
\text { TP_dw }\end{array}$} & \multirow{3}{*}{$\begin{array}{l}\text { Toxicological parameter (time) } \\
500 \mathrm{mg} \mathrm{L}^{-1} \text { (NOEC, 96h) } \\
500 \mathrm{mg} \mathrm{L}^{-1} \text { (NOEC, 96h) }\end{array}$} & \multicolumn{2}{|c|}{ Toxicological parameter (time) from literature } \\
\hline & & & & \multirow{2}{*}{\multicolumn{2}{|c|}{$>100 \mathrm{mg} \mathrm{L}^{-1}(\mathrm{EC} 50,48 \mathrm{~h})^{(1)}$ (Hydra vulgaris) }} \\
\hline & & & & & \\
\hline & \multirow[t]{2}{*}{$\mathrm{IBU}$} & TP_up & $100 \mathrm{mg} \mathrm{L}^{-1}$ (Calc. LC7, 96h) & \multirow{2}{*}{$\begin{array}{l}20 \mathrm{mg} \mathrm{L}^{-1}(\mathrm{LC} 50,72 \mathrm{~h}) \\
25 \mathrm{mg} \mathrm{L}^{-1}(\mathrm{LC} 50,96 \mathrm{~h})\end{array}$} & \multirow{2}{*}{$\begin{array}{l}\text { (2) }(\text { Planorbis carinatus }) \\
{ }^{(3)}(\text { Hydra attenuata })\end{array}$} \\
\hline & & TP_dw & $100 \mathrm{mg} \mathrm{L}^{-1}$ (NOEC, 96h) & & \\
\hline & TMP & $\begin{array}{l}\text { TP_up } \\
\text { TP_dw }\end{array}$ & $\begin{array}{l}400 \mathrm{mg} \mathrm{L}^{-1} \text { (NOEC, 96h) } \\
400 \mathrm{mg} \mathrm{L}^{-1} \text { (Calc. LC7, 96h) }\end{array}$ & $150 \mathrm{mg} \mathrm{L}^{-1}(\mathrm{EC} 50,48 \mathrm{~h})$ & (4) (Daphnia magna) \\
\hline & TCC & $\begin{array}{l}\text { TP_up } \\
\text { TP_dw }\end{array}$ & $\begin{array}{l}100 \mu \mathrm{g} \mathrm{L}^{-1} \text { (Calc. LC13, 96h) } \\
100 \mu \mathrm{g} \mathrm{L}^{-1} \text { (Calc. LC33, 96h) }\end{array}$ & $10 \mu \mathrm{g} \mathrm{L}^{-1}(\mathrm{EC} 50,48 \mathrm{~h})$ & (5) (Daphnia magna) \\
\hline \multirow[t]{13}{*}{ Diamesa zernyi } & FUR & PR0 & $500 \mathrm{mg} \mathrm{L}^{-1}(\mathrm{NOEC}, 96 \mathrm{~h})$ & \multicolumn{2}{|c|}{$>100 \mathrm{mg} \mathrm{L}^{-1}(\mathrm{EC} 50,48 \mathrm{~h}){ }^{(1)}$ (Hydra vulgaris) } \\
\hline & IBU & PR0 & $100 \mathrm{mg} \mathrm{L}^{-1}$ (Calc. LC33, 96h) & $\begin{array}{l}20 \mathrm{mg} \mathrm{L}^{-1}(\mathrm{LC} 50,72 \mathrm{~h}) \\
25 \mathrm{mg} \mathrm{L}^{-1}(\mathrm{LC} 50,96 \mathrm{~h})\end{array}$ & $\begin{array}{l}\text { (2) (Planorbis carinatus }) \\
\text { (3) (Hydra attenuata })\end{array}$ \\
\hline & TMP & PR0 & $400 \mathrm{mg} \mathrm{L}^{-1}(\mathrm{LOEC}, 96 \mathrm{~h})$ & $150 \mathrm{mg} \mathrm{L}^{-1}(\mathrm{EC} 50,48 \mathrm{~h})$ & (4) (Daphnia magna) \\
\hline & TCC & PR0 & $100 \mu \mathrm{g} \mathrm{L}^{-1}$ (Calc. LC7, 96h) & $10 \mu \mathrm{g} \mathrm{L}^{-1}(\mathrm{EC} 50,48 \mathrm{~h})$ & (5) (Daphnia magna) \\
\hline & $\overline{\text { SUCR }}$ & PR0 & $42.727 \mathrm{~g} \mathrm{~L}^{-1}$ (Calc. LC10, 96h) & $>10 \mathrm{~g} \mathrm{~L}^{-1}(\mathrm{LC} 50,96 \mathrm{~h})$ & ${ }^{(6)}$ (Nitocra spinipes) \\
\hline & TON & PR0 & $100 \mathrm{mg} \mathrm{L}^{-1}$ (Calc. LC7, 96h) & $0.2 \mathrm{mg} \mathrm{L}^{-1}(\mathrm{EC} 50,21 \mathrm{~d})$ & (7) (Daphnia magna) \\
\hline & $\overline{\mathrm{BOS}}$ & PR0 & $500 \mu \mathrm{g} \mathrm{L}^{-1}$ (NOEC, 96h) & $50 \mu \mathrm{g} \mathrm{L}^{-1}(\mathrm{LC} 50,48 \mathrm{~h})$ & (8) (Daphnia magna) \\
\hline & $\overline{\mathrm{CAP}}$ & PR0 & $\begin{array}{l}3.14 \mathrm{mg} \mathrm{L}^{-1}(\mathrm{LC} 10,24 \mathrm{~h}) \\
81.06 \mathrm{mg} \mathrm{L}^{-1}(\mathrm{LC} 50,24 \mathrm{~h})\end{array}$ & 7-10 mg L ${ }^{-1}(\mathrm{LC} 50,96 \mathrm{~h})$ & (9) (Daphnia magna) \\
\hline & $\overline{\mathrm{CPS}}$ & PR0 & $\begin{array}{l}1.06 \mu \mathrm{g} \mathrm{L}^{-1}(\mathrm{LC} 10,48 \mathrm{~h}) \\
5.24 \mu \mathrm{g} \mathrm{L}^{-1}(\mathrm{LC} 50,48 \mathrm{~h})\end{array}$ & $0.5 \mu \mathrm{g} \mathrm{L}^{-1}(\mathrm{LC} 50,96 \mathrm{~h})$ & ${ }^{(10)}$ (Chironomus tentans) \\
\hline & MET & PR0 & $\begin{array}{l}27.40 \mathrm{mg} \mathrm{L}^{-1}(\mathrm{LC} 10,72 \mathrm{~h}) \\
84.12 \mathrm{mg} \mathrm{L}^{-1}(\mathrm{LC} 50,72 \mathrm{~h})\end{array}$ & $3.8 \mathrm{mg} \mathrm{L}^{-1}(\mathrm{EC} 50,48 \mathrm{~h})$ & ${ }^{(11)}$ (Chironomus plumosus) \\
\hline & TER & PR0 & $25 \mathrm{mg} \mathrm{L}^{-1}$ (Calc. LC20, 96h) & $>5 \mathrm{mg} \mathrm{L}^{-1}(\mathrm{EC} 50,48 \mathrm{~h})$ & (12) (Daphnia magna) \\
\hline & MIX1K & PR0 & $10^{3} \mathrm{x}$ EC of CPS, MET, TER (Calc. LC3, 72h) & \multicolumn{2}{|l|}{ N.A. } \\
\hline & MIX10K & PR0 & $10^{4} \mathrm{x}$ EC of CPS, MET, TER (Calc. LC13, 24h) & \multicolumn{2}{|l|}{ N.A. } \\
\hline
\end{tabular}

FUR, furosemide; IBU, ibuprofene; TMP, trimethoprim; TCC, triclocarban; SUCR, sucralose; TON, tonalide; BOS, boscalid; CAP, captan; CPS, chlorpyrifos; MET, metolachlor; TER, terbuthylazine; MIX 1K, 103 x EC of CPS, MET, TER; MIX 10K, $10^{4}$ x EC of CPS, MET, TER. References for toxicological parameters from literature: ${ }^{1}$ (Pascoe et al., 2003); ${ }^{2}$ (Pounds et al., 2008); ${ }^{3}$ (Quinn et al., 2008); ${ }_{4}^{4}$ (De Liguoro et al., 2009); ${ }^{5}$ (Tamura et al., 2013); ${ }^{6}$ (Wiklund et al., 2012); ${ }^{7}$ (Grutzner, 1995); ${ }^{8}$ (Bundschuh et al., 2016); ${ }^{9}$ (Kamrin, 2000); ${ }^{10}$ (Ankley et al., 1994); ${ }^{11}$ (Mayer and Ellersieck, 1986); ${ }^{12}$ (Marchini et al., 1988). 
mechanisms of toxic action (Lydy et al., 2004; Johnson et al., 2013). The other two pesticides, BOS, a medium-risk fungicide, and TER, seemed harmless, like the drug FUR, as expected on the basis of its low level of risk. The other two pharmaceuticals, IBU and TMP, both classified as medium-risk, exhibited a different effect (even if not significant) on the three populations of Diamesa, without overcame $33 \%$ of dead larvae after $96 \mathrm{~h}$ at Cmax. A high general resistance was highlighted also to the three personal care products, even to the antibacterial TCC considered as dangerous for aquatic life (Lencioni et al., 2017).

A clear gradient of increasing resistance, from $D$. zernyi in PR0 to $D$. cinerella in the WTP downstream site, was detected only for IBU, reflecting a gradient of contamination of this substance in the environment from the least (PR0) to the most polluted (TP dw) site (Lencioni et al., 2017).

Both Diamesa species resulted more resistant to toxicants than any model species used to estimate toxicological parameters referred to the same 11 pollutants. The ratio between the toxicological parameters we measured and the literature data ranged from 3 (for TMP, in Diamesa spp. LOEC, $96 \mathrm{~h}=400 \mathrm{mg} \mathrm{L}^{-1}$ respect to D. magna LC50 $48 \mathrm{~h}=150 \mathrm{mg} \mathrm{L}^{-1}$, (De Liguoro et al., 2009) to 21 (for MET, in D. zernyi LC50 $72 \mathrm{~h}=84.12 \mathrm{mg}$ $\mathrm{L}^{-1}$ respect to C. plumosus LC50 $48 \mathrm{~h}=3.8$ (Mayer and
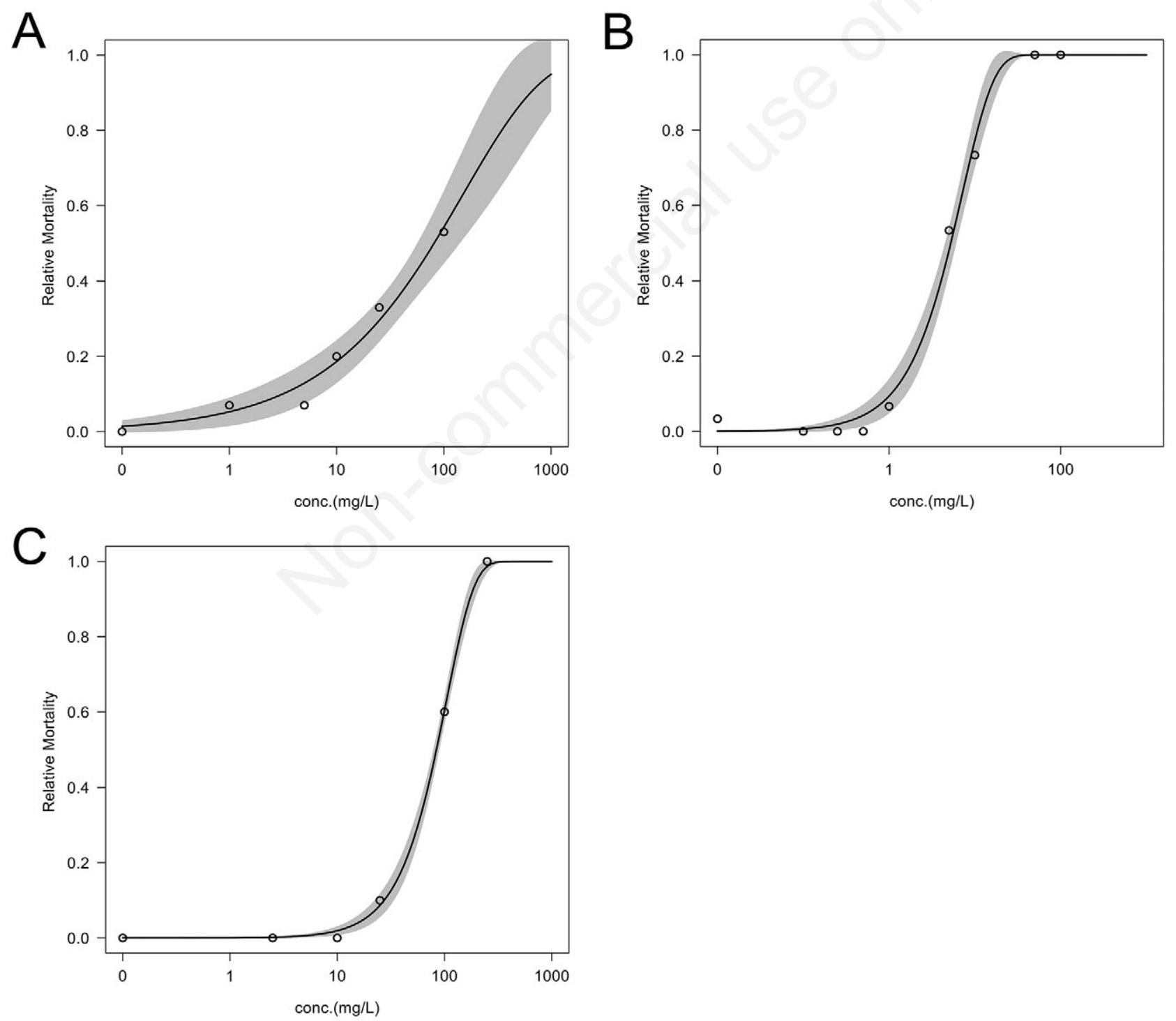

Fig. 2. Weibull distribution for (A) Captan, (B) Chlorpyrifos and (C) Metolachlor. Grey shaded areas surrounding the regression lines represent $95 \%$ confidence intervals for the regression. 
Ellersieck, 1986)). For TON an extraordinary high resistance was observed in D. zernyi (LC7 $96 \mathrm{~h}=100 \mathrm{mg}$ $\mathrm{L}^{-1}$ ) respect to D. magna EC50 $21 \mathrm{~d}=0.2 \mathrm{mg} \mathrm{L}^{-1}$ (Grutzner, 1995). For the other two pesticides with significant acute toxicity, this ratio was 8 for CAP (respect to D. magna (Kamrin, 2000)) and 10 for CPS (respect to C. tentans, Ankley et al., 1994).

Basal DNA damage was detected in both Diamesa species under natural conditions, with, as expected according to the contamination level, a higher basal DNA damage in $D$. cinerella living downstream of the WTP effluent. This suggests that $D$. cinerella colonizes this stream reach, but survives under physiological stress. This population accumulated less DNA damage than that living upstream when briefly exposed $(24 \mathrm{~h})$ to sub-lethal concentrations of the tested pollutants, highlighting a negative effect only by IBU. Conversely, the upstream population seemed more sensitive, undergoing damage also by FUR and TCC. The genotoxic activity of these pollutants decreased in the case of long-term exposure (96 $\mathrm{h}$ ) in the upstream population, due probably to the upregulation of the antioxidant defences and of DNA repair mechanisms as observed in other organisms (SantaGonzalez et al., 2016). In comparison, D. zernyi was the most sensitive species, accumulating, after four days of exposure, DNA damage by all pollutants tested, mixtures
A

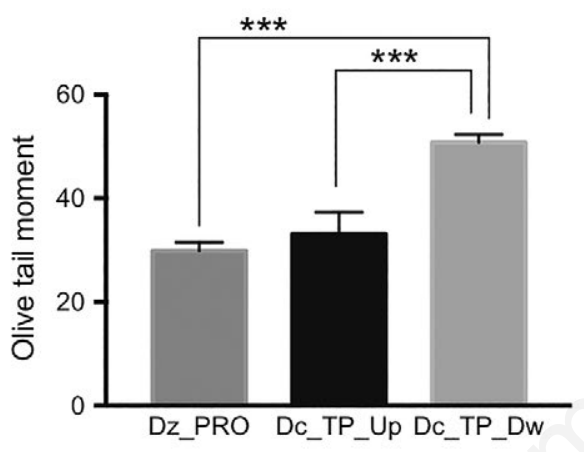

C

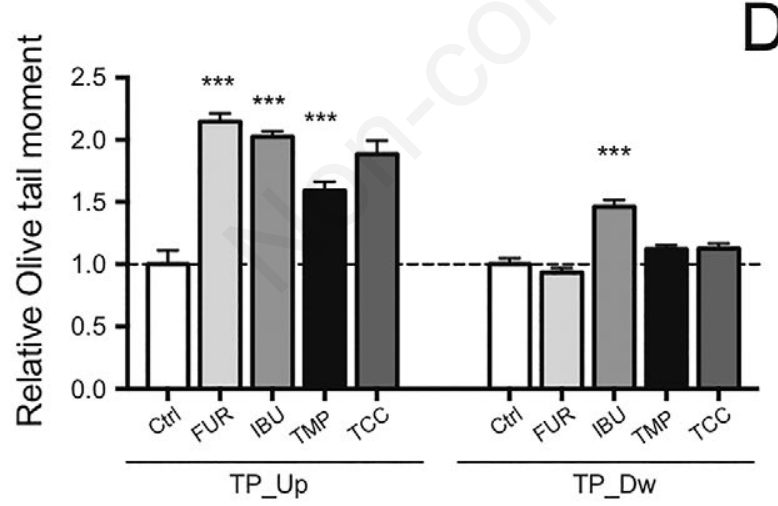

B
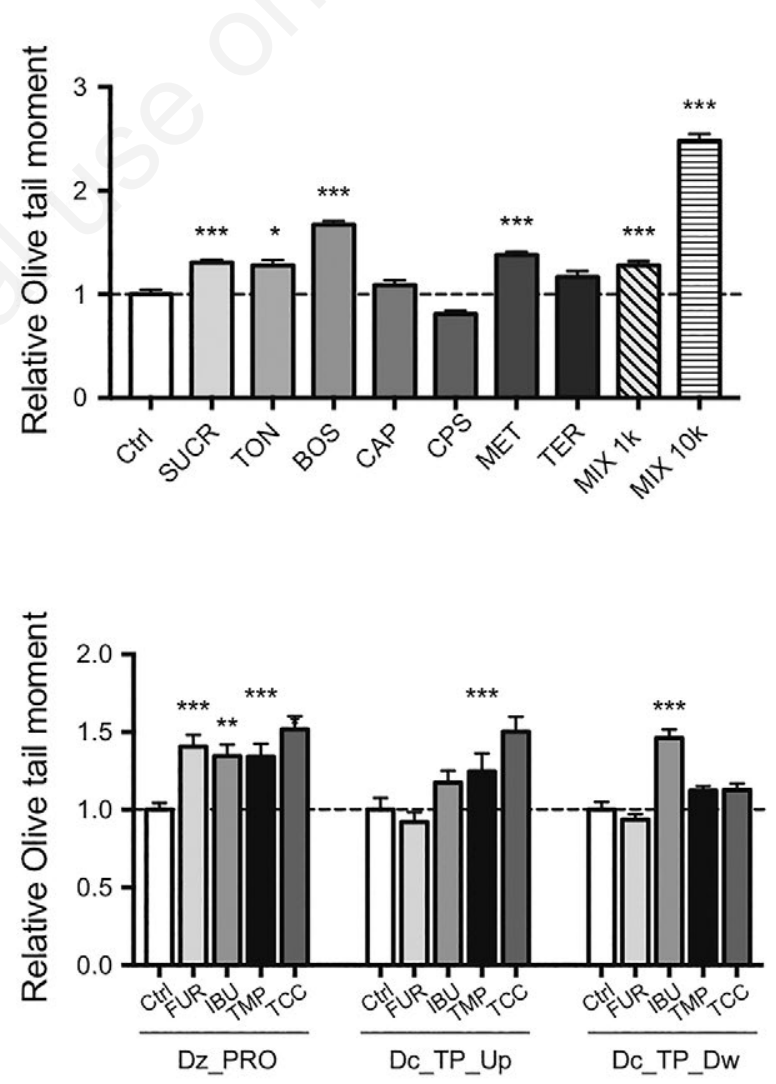

Fig. 3. A) Basal DNA damage measured by Olive Tail Moment (OTM) $\pm \mathrm{SE}$ in D. zernyi larvae collected in the Presena stream (Dz PRO) and in D. cinerella larvae collected in the Vermigliana stream upstream (Dc_TP_up) and downstream (TP_dw) of the Tonale Pass WTP. B) DNA damage by emerging contaminants (PPCPs=pharmaceuticals and personal care products) and pesticides measured as Relative OTM in D. zernyi from PR0. C) DNA damage by short term exposure (24 h) to PPCPs measured as Relative OTM in $D$. cinerella from TP up and TP dw. D) DNA damage by long term exposure $(96 \mathrm{~h})$ to PPCPs measured as Relative OTM in $D$. zernyi from PR0 (Dz_PRO) and in $D$. cinerella larvae from TP_up and TP_dw. The histograms show the mean of the (Relative) OTM \pm SE $(>100$ nuclei were counted per each condition). Relative OTM: OTM values were normalized each on its corresponding control. The DNA damage of the control was fixed to 1. Significant differences (Kruskal-Wallis test and multiple comparison Dunn test) from the corresponding control $(* \mathrm{P} \leq 0.05, * * \mathrm{P} 0.01, * * * \mathrm{P} \leq 0.001)$. In (B), (C) and (D), larvae were exposed at sublethal concentrations of each pollutant: LC10 estimated, LOEC, NOEC or calculated LC $<<\mathrm{LC} 50$, as reported in Tab. S2. FUR, furosemide; IBU, ibuprofene; TMP, trimethoprim; TCC,t riclocarban; SUCR, sucralose; TON, tonalide; BOS, boscalid; CAP, captan; CPS, chlorpyrifos; MET, metolachlor; TER, terbuthylazine; MIX 1K, $10^{3}$ x EC of CPS, MET, TER; MIX 10K, $10^{4}$ x EC of CPS, MET, TER. 
included, with the sole exception of CAP, CPS and TER. The no-genotoxic activity of CAP and CPS was unexpected, considering their acute toxicity. Overall, as observed for survival, these results highlighted a gradient of increasing resistance from the least (PR0) to the most polluted (TP_dw) site, with demonstrated sensitivity to 9 out of 11 pollutants in D. zernyi, 3 out of 4 in D. cinerella from TP_up and only 1 in $D$. cinerella from TP_dw.

The different general resistance observed in the two species/three populations might be explained according to the different level of environmental contamination and on the basis of the autecology of the two species. D. zernyi might be more sensitive compared to $D$. cinerella because the species was collected in a less impacted environment, while it is plausible that $D$. cinerella from TP_dw had developed chemical resistance strategies to survive already under natural conditions and that the tested larvae were somehow pre-adapted to these pollutants. According to autecology, D. zernyi was hypothesised to be more sensitive than $D$. cinerella because typically restricted to very cold and pristine habitats (Lencioni and Rossaro, 2005).

Acute toxicity tests and Comet assay gave the same danger level for the 11 pollutants, some being ecotoxic but not genotoxic (e.g., CPS, CAP) and vice versa (e.g., FUR, TMP). A risk ranking might be suggested based on the results of both tests in both species, recognising as the most dangerous MET, IBU and TCC.

The observed high resistance to drugs, personal care products and pesticides observed in Diamesa spp. was unexpected, being considered species typical of pristine unpolluted habitats (Lencioni et al., 2012). This might be a secondary effect of their strong cold resistance (e.g., Supercooling Point $=-6.3 \pm 0.3^{\circ} \mathrm{C}$, LLT $100=-16.2^{\circ} \mathrm{C}$, thermal hysteresis $>2$, accumulation of glucose and sucrose and antifreeze proteins (Lencioni and Bernabò, 2017). Furthermore, Diamesa spp. develops a Heat Shock Response under thermal stress (Lencioni et al., 2013), and it is know that HSP70 have been involved in increasing toxic resistance (Karouna-Renier and Zehr, 2003). In fact, it is known that organisms living in extremely cold environments have evolved physiological traits that can have a major influence on the sensitivity of species towards contaminants, influencing their resistance (Chapman, 2016). Another reason of the extraordinary high resistance even to high-risk pollutants at concentrations million times higher than the $\mathrm{EC}$, might be that at low water temperature toxicity of some contaminants (e.g. CPS) is lower than at high temperature (Patra et al., 2015). Furthermore, there is increasing evidence of a delay in the manifestation of toxicity with exposure to contaminants in polar (Arctic and Antarctic) marine environments. This is probably due to multiple factors (e.g., slower uptake kinetics, slower metabolic rate, higher lipid storage at low temperature (Peck, 2002;
Chapman and Riddle, 2005; Payne et al., 2014). However, this phenomenon yet to be demonstrated in cold (e.g., $<4^{\circ} \mathrm{C}$ ) freshwater habitats (Chapman, 2016). In future, toxicity testing protocols should investigate this phenomenon, for example by setting a longer exposure time than $96 \mathrm{~h}$ to account for a delayed response, at even lower pollutant concentration and at a higher temperature within the thermal limit of the species and environmentally realistic even under global warming. In fact, possibly we underestimated the toxicity of some pollutants (due to low temperature and short time) and overestimated predicted no effect concentrations.

\section{CONCLUSIONS}

Even if measured concentrations of CECs and pesticides are far lower than those required to cause acute effects, prolonged exposure to a mixture of CECs might have damage macroinvertebrate communities, with cascade effects on the river food web. The unknown magnitude of top-down effects and trophic cascades should be considered in future experiments. Assuming that toxicants can damage or influence DNA in a variety of ways, other approaches (e.g., gene expression analyses of genes involved in responding to chemical stress in natural populations) might be very useful to understand the molecular mechanisms of organismal response to human-derived ecosystem change (Bernabò et al., 2017; Krosch et al., 2017). Threats posed by contamination by CECs even at high altitude make it important to expand knowledge concerning heat and chemical tolerance in stenothermal insect species from freshwaters already threatened by temperature changes.

\section{ACKNOWLEDGMENTS}

This work was supported by the Cassa di Risparmio di Trento e Rovereto Foundation (CARITRO) within the RACE-TN project ("Valutazione del rischio ambientale dei contaminanti emergenti nei fiumi trentini: effetti sulla vita selvatica e sull'uomo"/"Environmental Risk assessment of emerging contaminants in Trentino rivers: effects on wildlife and human health", Grant n. 2015.0199; 2015-2018). We are very grateful to: Alberto Bellin (University of Trento, Italy) for providing data on contamination by pharmaceuticals in the study sites at the beginning of the project; Alessandra Franceschini and Francesca Paoli (MUSE-Science Museum, Italy) for their help in the field and laboratory activities; Sara Villa and Valeria Di Nica (University of Milano-Bicocca, Italy) for fruitful discussion on the laboratory protocols, for providing PECsw and hazard level of CECs, and for measuring sucralose and pesticide concentrations; Sara 
Castiglioni (Institute of Pharmacological Research "Mario Negri", Milano, Italy) for pharmaceutical detection; Sonia Ciccazzo (Free University of Bolzano, Italy) for performing some comet assay tests on D. cinerella; Massimo Paolazzi (APPA, Trentino Environmental Agency, Trento, Italy) for chemical analyses of stream water; Francesca Paoli for drawing the map of the study area (Fig. 1); two anonymous reviewers for their helpful and constructive comments that greatly improved the final version of this paper. Part of the dataset was included in the master thesis of the last two authors (FM, University of Genova; AS, University of Parma; Italy).

\section{REFERENCES}

Ankley GT, Call DJ, Cox JS, Kahl MD, Hoke RA, Kosian PA, 1994. Organic carbon partitioning as a basis for predicting the toxicity of chlorpyrifos in sediments. Environ. Toxicol. Chem. 13:621-626.

Bernabò P, Gaglio M, Bellamoli F, Viero G, Lencioni V, 2017. DNA damage and translational response during detoxification from copper exposure in a wild population of Chironomus riparius. Chemosphere 173:235-244.

Brown LE, Khamis K, Wilkes M, Blaen P, Brittain JE, Carrivick JL, Fell S, Friberg N, Füreder L, Gislason GM, Hainie S, Hannah DM, et al., 2018. Functional diversity and community assembly of river invertebrates show globally consistent responses to decreasing glacier cover. Nat. Ecol. Evol. 2:325-333.

Bundschuh M, Elsaesser D, Stang C, Schulz R, 2016. Mitigation of fungicide pollution in detention ponds and vegetated ditches within a vine-growing area in Germany. Ecol. Eng. 89:121-130.

Chapman PM, 2016. Toxicity delayed in cold freshwaters? J. Great Lakes Res. 42:286-289.

Chapman PM, Riddle MJ, 2005. Toxic Effects of Contaminants in Polar Marine Environments. Environ. Sci. Technol. 39:200A-207A.

Chiogna G, Majone B, Cano Paoli K, Diamantini E, Stella E, Mallucci S, Lencioni V, Zandonai F, Bellin A, 2016. A review of hydrological and chemical stressors in the Adige catchment and its ecological status. Sci. Total Environ. 540:429-443.

Daughton CG, Ternes TA, 1999. Pharmaceuticals and personal care products in the environment: Agents of subtle change? Environ. Health Perspect.107: 907-938.

Dong Y, Wang J, Ding L, Liu Y, 2013. Influence of Cosolvents on Low Water-Solubility Chemicals to Photobacterium phosphoreum in Acute Toxicity Test. Procedia Environ. Sci. 18:143-148.

Ferrario C, Finizio A, Villa S, 2017. Legacy and emerging contaminants in meltwater of three Alpine glaciers. Sci. Total Environ. 574:350-357.

Grutzner I, 1995. Influence of Musk Ketone on the Reproduction of Daphnia magna. Report to RIFM, RCC, Switzerland. Project 380676.

Guzzella L, Salerno F, Freppaz M, Roscioli C, Pisanello F, Poma G, 2016. POP and PAH contamination in the southern slopes of Mt. Everest (Himalaya, Nepal): Long-range atmospheric transport, glacier shrinkage, or local impact of tourism? Sci. Total Environ. 544:382-390.

Holdway DA, 2005. Hydra population reproduction toxicity test method, p. 395-411 In: Small-Scale Freshwater Toxicity Investigations: Volume 1 - Toxicity Test Methods.

Johnson LA, Welch B, Whitfield SM, 2013. Interactive effects of pesticide mixtures, predators, and environmental regimes on the toxicity of two pesticides to red-eyed tree frog larvae. Environ. Toxicol. Chem. 32:2379-2386.

Kamrin MA, 2000. Pesticide Profiles: Toxicity, Environmental Impact, and Fate. CRC Press LLC: 704 pp.

Karouna-Renier NK, Zehr JP, 2003. Short-term exposures to chronically toxic copper concentrations induce HSP70 proteins in midge larvae (Chironomus tentans). Sci. Total Environ. 312:267-272.

Krosch MN, Bryant LM, Vink S, 2017. Differential gene expression of Australian Cricotopus draysoni (Diptera: Chironomidae) populations reveals seasonal association in detoxification gene regulation. Sci. Rep. 7: 14263.

Lee S-W, Kim S-M, Choi J, 2009. Genotoxicity and ecotoxicity assays using the freshwater crustacean Daphnia magna and the larva of the aquatic midge Chironomus riparius to screen the ecological risks of nanoparticle exposure. Environ. Toxicol. Pharmacol. 28:86-91.

Lencioni V, 2018. Glacial influence and stream macroinvertebrate biodiversity under climate change: Lessons from the Southern Alps. Sci. Total Environ. 622623:563-575.

Lencioni V, Bernabò P, 2017. Thermal survival limits of young and mature larvae of a cold stenothermal chironomid from the Alps (Diamesinae: Pseudodiamesa branickii [Nowicki, 1873]). Insect Sci. 24:314-324.

Lencioni V, Bernabò P, Cesari M, Rebecchi L, 2013. Thermal stress induces hsp70 proteins synthesis in larvae of the cold stream non-biting midge Diamesa cinerella Meigen. Arch. Insect Biochem. Physiol. 83:1-14.

Lencioni V, Jousson O, Guella G, Bernabò P, 2015. Cold adaptive potential of chironomids overwintering in a glacial stream. Physiol. Entomol. 40:43-53.

Lencioni V, Marziali L, Rossaro B, 2012. Chironomids as bioindicators of environmental quality in mountain springs. Freshw. Sci. 31:525-541.

Lencioni V, Rossaro B, 2005. Microdistribution of chironomids (Diptera: Chironomidae) in Alpine streams: An autoecological perspective. Hydrobiologia. 533:61-76.

Lencioni V, Villa S, Di Nica V, Castiglioni S, Menegon M, 2017. Environmental Risk assessment of emerging contaminants in Trentino rivers: effects on wildlife and human health", Grant n. 2015.0199; 2015-2017. Annual Scientific Report 2017 (Prot. N. MTSN-0002656-14/04/2017-P): 205 pp.

Liguoro M De, Fioretto B, Poltronieri C, Gallina G, 2009. The toxicity of sulfamethazine to Daphnia magna and its additivity to other veterinary sulfonamides and trimethoprim. Chemosphere 75:1519-1524.

Lydy M, Belden J, Wheelock C, Hammock B, Denton D, 2004. Challenges in regulating pesticide mixtures. Ecol. Soc. 9:1.

Mandaric L, Diamantini E, Stella E, Cano-Paoli K, Valle-Sistac J, Molins-Delgado D, Bellin A, Chiogna G, Majone B, DiazCruz MS, Sabater S, Barcelo D, et al., 2017. Contamination 
sources and distribution patterns of pharmaceuticals and personal care products in Alpine rivers strongly affected by tourism. Sci. Total Environ. 590-591:484-494.

Marchini S, Passerini L, Cesareo D, Tosato ML, 1988. Herbicidal triazines: Acute toxicity on Daphnia, fish, and plants and analysis of its relationships with structural factors. Ecotoxicol. Environ. Saf. 16:148-157.

Martínez-Paz P, Morales M, Martínez-Guitarte JL, Morcillo G, 2013. Genotoxic effects of environmental endocrine disruptors on the aquatic insect Chironomus riparius evaluated using the comet assay. Mutat. Res. Toxicol. Environ. Mutagen. 758:41e47.

Mayer FLL, Ellersieck MRMR, 1986. Manual of acute toxicity: interpretation and data base for 410 chemicals and 66 species of freshwater animals. Ellersieck, United States Department of the Interior, U.S. Fish and Wildlife Service, Resource Publication 160.

Milner AM, Brown LE, Hannah DM, 2009. Hydroecological response of river systems to shrinking glaciers. Hydrol Process. 23:62-67.

Milner AM, Khamis K, Battin TJ, Brittain JE, Barrand NE, Füreder L, Cauvy-Fraunié S, Gíslason GM, Jacobsen D, Hannah DM, Hodson AJ, Hood E, et al., 2017. Glacier shrinkage driving global changes in downstream systems. Proc. Natl. Acad. Sci. 114: 9770-9778.

Olive PL, Banáth JP, 2006. The comet assay: a method to measure DNA damage in individual cells. Nat. Protoc. 1:23-29.

Pascoe D, Karntanut W, Müller CT, 2003. Do pharmaceuticals affect freshwater invertebrates? A study with the cnidarian Hydra vulgaris. Chemosphere 51:521-528.

Patra RW, Chapman JC, Lim RP, Gehrke PC, Sunderam RM, 2015. Interactions between water temperature and contaminant toxicity to freshwater fish. Environ. Toxicol. Chem. 34:1809-1817.

Payne SJ, King CK, Zamora LM, Virtue P, 2014. Temporal changes in the sensitivity of coastal Antarctic zooplankton communities to diesel fuel: A comparison between singleand multi-species toxicity tests. Environ. Toxicol. Chem. 33:882-890.

Peck LS, 2002. Ecophysiology of Antarctic marine ectotherms: Limits to life. Polar Biol. 25:31-40.

Pounds N, Maclean S, Webley M, Pascoe D, Hutchinson T,
2008. Acute and chronic effects of ibuprofen in the mollusc Planorbis carinatus (Gastropoda: Planorbidae). Ecotoxicol. Environ. Saf. 70:47-52.

Quinn B, Gagné F, Blaise C, 2008. An investigation into the acute and chronic toxicity of eleven pharmaceuticals (and their solvents) found in wastewater effluent on the cnidarian, Hydra attenuata. Sci. Total Environ. 389:306-314.

Ritz C, Baty F, Streibig JC, Gerhard D, 2015. Dose-response analysis using R. PLoS One 10: e0146021.

Rossaro B, Lencioni V, 2015. A key to larvae of species belonging to the genus Diamesa from Alps and Apennines (Italy). Eur. J. Environ. Sci. 5:62-79.

Rossaro B, Montagna M, Lencioni V, 2016. Environmental traits affect chironomid communities in glacial areas of the Southern Alps: Evidence from a long-lasting case study. Insect Conserv. Divers. 9:192-201.

Santa-Gonzalez GA, Gomez-Molina A, Arcos-Burgos M, Meyer JN, Camargo M, 2016. Distinctive adaptive response to repeated exposure to hydrogen peroxide associated with upregulation of DNA repair genes and cell cycle arrest. Redox Biol. 9:124-133.

Steinlin C, Bogdal C, Lüthi MP, Pavlova PA, Schwikowski M, Zennegg M, Schmid P, Scheringer M, Hungerbühler K, 2016. A Temperate Alpine Glacier as a Reservoir of Polychlorinated Biphenyls: Model Results of Incorporation, Transport, and Release. Environ. Sci. Technol. 50:5572-5579.

Tamura I, Kagota KI, Yasuda Y, Yoneda S, Morita J, Nakada N, Kameda Y, Kimura K, Tatarazako N, Yamamoto H, 2013. Ecotoxicity and screening level ecotoxicological risk assessment of five antimicrobial agents: Triclosan, triclocarban, resorcinol, phenoxyethanol and p-thymol. J. Appl. Toxicol. 33:1222-1229.

Valverde M, Rojas E, 2009. Environmental and occupational biomonitoring using the Comet assay. Mutat. Res. 681: 93-109.

Villa S, Di Nica V, Pescatore T, Bellamoli F, Miari F, Finizio A, Lencioni V, 2018. Comparison of the behavioural effects of pharmaceuticals and pesticides on Diamesa zernyi larvae (Chironomidae). Env. Poll. 238:130-139.

Wiklund AKE, Breitholtz M, Bengtsson BE, Adolfsson-Erici M, 2012. Sucralose - An ecotoxicological challenger? Chemosphere 86:50-55. 